\title{
Effect of different rates of $P$ fertilization on the yield and $P$ status of the soil in two long-term field experiments
}

\author{
MARKKU YLI-HALLA \\ Kemira Oy, Espoo Research Centre, Luoteisrinne 2, \\ SF-0227I Espoo, Finland
}

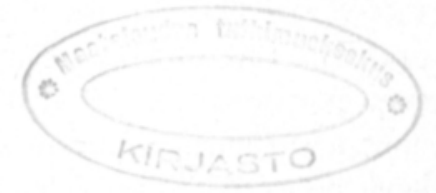

\begin{abstract}
Two field experiments on P fertilization were conducted on clay soils in Southern Finland. The rates of P applied yearly in granular NPK fertilizers were $0,13 / 16,26 / 32$, $47 / 56$ and $60 / 72 \mathrm{~kg} \mathrm{P} / \mathrm{ha}$ in $1974-82 / 1983-85$. Oats, barley, spring wheat and winter wheat were grown, in two years also oil seed crops. In one experiment, the maximum yield of cereal grains in the first nine years $(4460 \mathrm{~kg} / \mathrm{ha}$ ) was reached at the $\mathrm{P}$ rate of $13 \mathrm{~kg} / \mathrm{ha}$, but thereafter at $32 \mathrm{~kg} \mathrm{P} / \mathrm{ha}$. The average difference between the maximum yields and the ones obtained without $\mathrm{P}$ fertilization was $470 \mathrm{~kg} / \mathrm{ha}(12 \%)$ in $1974-80$, but during the last four years the difference increased to $1360 \mathrm{~kg} / \mathrm{ha}(40 \%)$, owing to the depletion of $\mathrm{P}$ in the plots not fertilized with P. Also in the other experiment, in which the maximum yield of cereal grains (4 $790 \mathrm{~kg} / \mathrm{ha}$ ) was obtained at the $\mathrm{P}$ rate of $26 / 32 \mathrm{~kg} / \mathrm{ha}$, the response to $\mathrm{P}$ fertilization increased towards the end of the trial, the mean response during the last three years being $570 \mathrm{~kg} / \mathrm{ha}(12 \%)$. Phosphorus fertilization, up to the P level at which the maximum yield was reached, decreased the moisture content of cereal grains at harvest. The quantity of $\mathrm{P}$ extracted with $0.5 \mathrm{M} \mathrm{NH}_{4}$-acetate- $0.5 \mathrm{M}$ acetic acid ( $\mathrm{pH} \mathrm{4.65)}$ decreased in the plots not fertilized with $\mathrm{P}$, from $5.8 \mathrm{mg} / \mathrm{l}$ to $2.2 \mathrm{mg} / \mathrm{l}$ and from $6.2 \mathrm{mg} / \mathrm{l}$ to $1.8 \mathrm{mg} / \mathrm{l}$ in the course of the two trials. The original level of acetate-extractable $\mathrm{P}$ was somewhat maintained but not elevated by $\mathrm{P}$ rates of $26 / 32,47 / 56$ and $60 / 72 \mathrm{~kg} / \mathrm{ha}$. Residual $\mathrm{P}$ was recovered mainly in the fractions extractable with $\mathrm{NH}_{4} \mathrm{~F}$ ("'Al-P") and $\mathrm{NaOH}$ ("Fe-P").
\end{abstract}

Index words: phosphorus fractionation, soil analysis, long-term experiments

\section{Introduction}

Plants take up phosphorus from the fertilizer being applied currently as well as from the previous reserves contained in the soil. Field experiments conducted in the USA and Australia recently showed that only $9-23 \%$
(Sharpley 1986) or $16 \%$ (McLaughlin et al. 1988) of $\mathrm{P}$ taken up by wheat plants originated in the $\mathrm{P}$ fertilization applied simultaneously with sowing, and that the rest came from the $P$ reserves of the soil. The results of an exten- 
sive series of fied experiments performed in Finland (SAarela 1989) showed that less response to $\mathrm{P}$ fertilization was obtained in soils moderately high in easily soluble $\mathrm{P}$ than in soils low in easily soluble P. Those results imply that in soils high in easily soluble P, current fertilization has only a minor contribution to the P supply to the plants. Besides soil properties, the quantity of plant-available $\mathrm{P}$ in the soil depends to a large extent on the applications of fertilizer $\mathrm{P}$ given to the soil in the past (Jankovic and Nemeth 1979, HarTIKAINEN 1989b). In order to assess the appropriate rate of $\mathrm{P}$ fertilization in the long run, experiments on $\mathrm{P}$ fertilization need to have a sufficient duration so that also the labile pool of $\mathrm{P}$ in the soil has time to be modified to the size determined by the rate of $\mathrm{P}$ fertilization. Further, long-term field experiments are needed for the calibration of soil fertility tests.

The present paper is based on the results of two field experiments which lasted 11 or 12 years. The aim is to contribute to the determination of the level of $\mathrm{P}$ fertilization at which the supply of $\mathrm{P}$ to the crop does not limit yield formation but, on the other hand, does not lead to a build-up of unnecessarily high levels of easily soluble P in the soil. Therefore, in addition to the quantity and quality of the yield, the P status of the plots receiving repeated applications of fertilizer $\mathrm{P}$ was examined.

\section{Materials and methods}

Two field trials, called here experiment $\mathrm{A}$ and $\mathrm{B}$, were set up in spring and autumn of
1974, respectively, and continued until 1985 at Kotkaniemi experimental farm in Vihti, Southern Finland. The trials were laid out on clay fields according to the randomized block method with four plots in experiment $\mathrm{A}$ and three plots in experiment B. The size of the plots was 3 by $25 \mathrm{~m}$ and 5.5 by $20 \mathrm{~m}$ in experiment $\mathrm{A}$ and $\mathrm{B}$, respectively. Initially and nearly every year in the course of the trials, the plots were sampled and analyzed for $\mathrm{P}$ and $\mathrm{pH}$. Phosphorus was extracted with $0.5 \mathrm{M}$ $\mathrm{NH}_{4}$-acetate $-0.5 \mathrm{M}$ acetic acid at $\mathrm{pH} 4.65$, abbreviated AAAc (VUORINEN and MÄ́ıTIE $1955)$, and the $\mathrm{pH}$ was measured in water suspension using the soil-to-water ratio of $1: 2.5$. At the end of the experiment, a composite sample of about $25 \mathrm{~kg}$ was taken from each plot and analyzed for the particle size distribution and organic carbon. The samples were also analyzed for poorly crystalline $\mathrm{Fe}$ and $\mathrm{Al}$, extractable with $0.05 \mathrm{M} \mathrm{NH}_{4}$-oxalate at $\mathrm{pH}$ 3.3 (HARTIKAINEN 1982) as well as for watersoluble P (Hartikainen 1982). Some properties of the experimental fields are listed in Table 1. Further, inorganic $\mathrm{P}$ of the samples taken at the end of the trials, was fractionated according to a slightly modified version of Chang and Jackson's procedure (HARTIKAINEN 1979).

The granular compound fertilizers for the experiments were manufactured at the pilot plant of Kemira Oy Espoo Research Centre. The fertilizers had increasing concentrations of P (Table 2). Nitrogen fertilization together with sowing was $100 \mathrm{~kg}$ (N/ha in 1974-1982 and $120 \mathrm{~kg} \mathrm{~N} /$ ha in $1983-85$. Potassium fertilization was 80 and $96 \mathrm{~kg} \mathrm{~K} / \mathrm{ha}$, respectively. The rates of $\mathrm{P}$ were $0,13,26,47$ and 60

Table 1. Some properties of the experimental fields.

\begin{tabular}{|c|c|c|c|c|c|c|}
\hline \multirow[t]{2}{*}{ Experiment } & \multirow{2}{*}{$\begin{array}{c}\text { Clay } \\
\%\end{array}$} & \multirow{2}{*}{$\begin{array}{c}\text { Organic C } \\
\%\end{array}$} & \multirow[t]{2}{*}{$\mathrm{pH}$} & \multirow{2}{*}{$\begin{array}{l}\mathrm{P}_{\mathrm{AMc}} \\
\mathrm{mg} / \mathrm{I}\end{array}$} & $\mathrm{Al}$ & $\mathrm{Fe}$ \\
\hline & & & & & \multicolumn{2}{|c|}{$\mathrm{mmol} / \mathrm{kg}$} \\
\hline $\begin{array}{l}\text { A: mean } \\
\text { range }\end{array}$ & $\begin{array}{c}37 \\
27-44\end{array}$ & $\begin{array}{c}3.3 \\
2.6-4.0\end{array}$ & $\begin{array}{c}5.4 \\
5.3-5.6\end{array}$ & $\begin{array}{c}5.4 \\
4.5-6.2\end{array}$ & $\begin{array}{c}84 \\
72-100\end{array}$ & $\begin{array}{c}71 \\
64-77\end{array}$ \\
\hline $\begin{array}{l}\text { B: mean } \\
\text { range }\end{array}$ & $25-40$ & $\begin{array}{c}3.4 \\
2.1-5.1\end{array}$ & $\begin{array}{c}6.0 \\
5.8-6.1\end{array}$ & $\begin{array}{c}6.0 \\
5.8-6.1\end{array}$ & $\begin{array}{c}64 \\
52-86\end{array}$ & $\begin{array}{c}85 \\
76-91\end{array}$ \\
\hline
\end{tabular}


Table 2. Composition of the experimental fertilizers.

\begin{tabular}{lccc}
\hline P fertilization & \multicolumn{3}{c}{ Concentration } \\
\cline { 2 - 4 } $\mathrm{kg} / \mathrm{ha}$ & $\mathrm{N}$ & $\mathrm{P}$ & $\mathrm{K}$ \\
& $\%$ & $\%$ & $\%$ \\
\hline 0 & 19 & 0 & 16 \\
$13 / 16$ & 15 & 2 & 12 \\
$26 / 32$ & 15 & 4 & 12 \\
$47 / 56$ & 15 & 7 & 12 \\
$60 / 72$ & 15 & 9 & 12 \\
\hline
\end{tabular}

Table 3. Crops and varieties grown in the field experiments.

\begin{tabular}{|c|c|c|c|c|}
\hline \multirow[t]{2}{*}{ Year* } & \multicolumn{2}{|c|}{ Experiment A } & \multicolumn{2}{|c|}{ Experiment B } \\
\hline & Crop & Variety & Crop & Variety \\
\hline 1974 & Spring wheat & Tähti & & \\
\hline 1975 & " & $"$ & Winter wheat & Aura \\
\hline 1976 & $n$ & $"$ & " & " \\
\hline 1977 & Oats & Ryhti & $"$ & " \\
\hline 1978 & " & $"$ & Oats & Ryhti \\
\hline 1979 & $"$ & $"$ & $"$ & $"$ \\
\hline 1980 & Barley & Aapo & Turnip rape & Torch \\
\hline 1981 & " & $"$ & Spring wheat & Tähti \\
\hline 1982 & $"$ & $"$ & Spring rape & Lergo \\
\hline 1983 & Spring wheat & Tapio & Spring wheat & Tapio \\
\hline 1984 & $"$ & $"$ & $n$ & " \\
\hline 1985 & $"$ & Ruso & Barley & Aapo \\
\hline
\end{tabular}

- The year of harvest

\section{Experiment $A$}

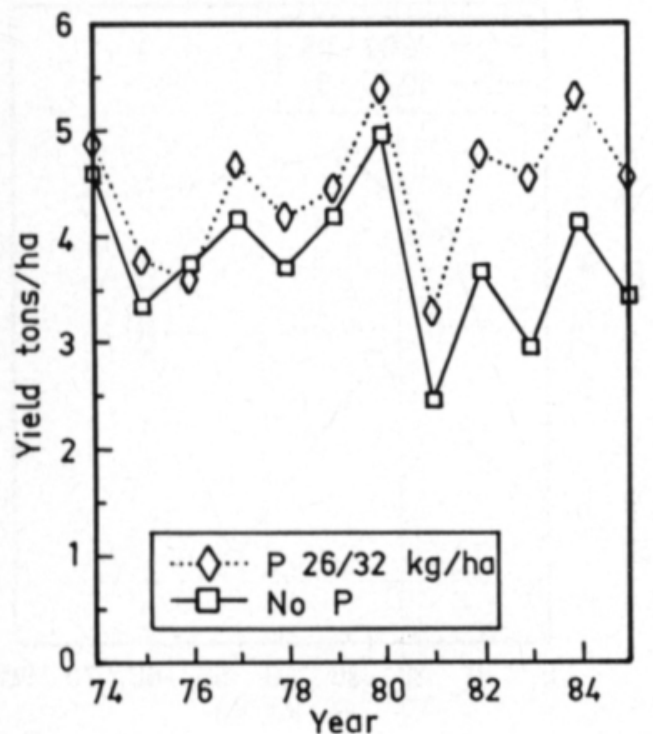

$\mathrm{kg} \mathrm{P} /$ ha until 1982 and $0,16,32,56$ and 72 $\mathrm{kg} \mathrm{P} / \mathrm{ha}$ in $1983-85$. Dividing the quantity of $\mathrm{P}$ applied to the plots during the whole period by the number of experimental years gave average $\mathrm{P}$ rates of $0,14,28,49$ and $63 \mathrm{~kg}$ $\mathrm{P} /$ ha. The fertilization together with sowing was performed according to the placement method. Spring wheat, barley and oats were cultivated (Table 3 ) in experiment $\mathrm{A}$, but in experiment B also winter wheat and oil seed crops were grown. Winter wheat received 55 $\mathrm{kg} \mathrm{N} / \mathrm{ha}$ in spring, in addition to the NPK fertilization applied in the previous fall together with sowing. After harvest, the grain or seed yields were weighed and their moisture content was determined. The grains and seeds were analyzed for $\mathrm{P}$ by a vanado-molybdate method (SAARI and PAASO 1980). The straw was ploughed under.

\section{Results}

The yields of cereal crops varied from year to year, mainly because of weather conditions. In the plots fertilized yearly with $26 / 32 \mathrm{~kg}$ $\mathrm{P} / \mathrm{ha}$, the grain yields ranged from 3270

Experiment $\mathrm{B}$

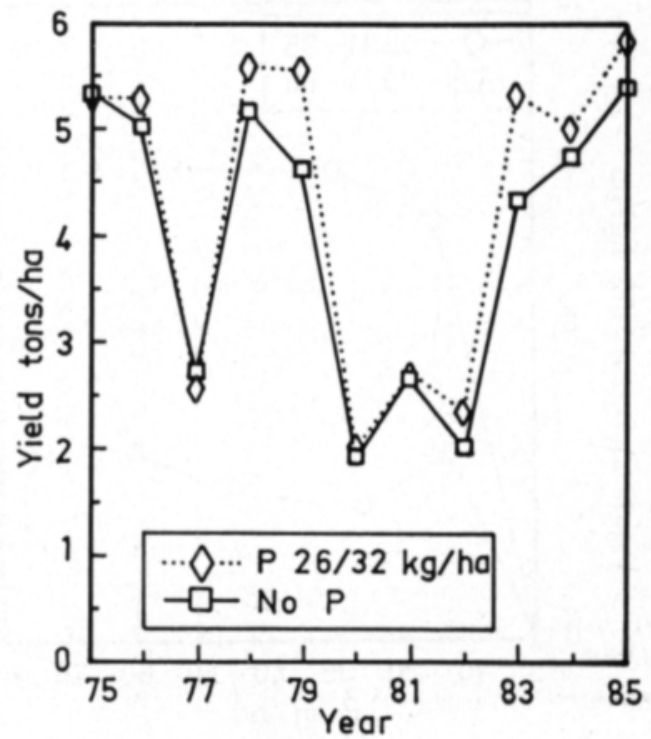

Fig. 1. Grain and seed yields in the two experiments at $\mathrm{P}$ rates of 0 and $26 / 32 \mathrm{~kg} \mathrm{P} / \mathrm{ha}$. 
Table 4. Grain and seed yields in the plots fertilized with different quantities of $\mathrm{P}^{*}$.

\begin{tabular}{|c|c|c|c|}
\hline \multirow{2}{*}{$\begin{array}{l}\text { Fertilization } \\
\text { kg P/ha }\end{array}$} & \multicolumn{2}{|c|}{ Grain yield } & \multirow{2}{*}{$\begin{array}{c}\text { Oil seed yield } \\
\text { Experiment B \#\# \# } \\
\mathrm{kg} / \mathrm{ha}\end{array}$} \\
\hline & $\begin{array}{c}\text { Experiment } A \# \\
\mathrm{~kg} / \mathrm{ha}\end{array}$ & $\begin{array}{c}\text { Experiment } \mathrm{B} \# \# \\
\mathrm{~kg} / \mathrm{ha}\end{array}$ & \\
\hline 0 & $3750^{b}$ & $4430^{b}$ & $1940^{\prime \prime}$ \\
\hline $13 / 16$ & $4470^{3}$ & $4660^{a b}$ & $1880^{\prime \prime}$ \\
\hline $26 / 32$ & $4440^{\mathrm{a}}$ & $4790^{-3}$ & $2160^{m}$ \\
\hline $47 / 56$ & $4440^{-2}$ & $4550^{b}$ & $1950^{\circ}$ \\
\hline $60 / 72$ & $4550^{\circ}$ & $4810^{2}$ & $2030^{-1}$ \\
\hline
\end{tabular}

* Each column has been tested separately. Means with a common letter are not different at the $95 \%$ of statistical probability.

\# 12 years

\#\# 9 years

\#\#\#2 years

$\mathrm{kg} / \mathrm{ha}$ to $5360 \mathrm{~kg} / \mathrm{ha}$ and from $2570 \mathrm{~kg} / \mathrm{ha}$ to $5800 \mathrm{~kg} / \mathrm{ha}$ in experiment $\mathrm{A}$ and $\mathrm{B}$, respectively (Fig. 1). In 1977 the low yield of winter wheat in experiment B was caused by winter damages, and in 1981 the yields were low in both trials because the weather was wet and exceptionally cool. The coefficients of variation $(\mathrm{s} / \overline{\mathrm{x}})$ for grain yields were $15 \%$ and $26 \%$ in experiment $\mathrm{A}$ and $\mathrm{B}$, respectively. According to analysis of variance and the Student-Neuman-Keuls' test (SteEl and Torrie
1980), $\mathrm{P}$ fertilization increased the average yields of cereal crops statistically significantly in both experiments (Table 4). The increase was greater and more consistent in experiment A $\left(\mathrm{F}=38.54^{* * *}\right)$ than in experiment $\mathrm{B}(\mathrm{F}=$ $\left.5.50^{* * *}\right)$. The oil seed crops, cultivated in two years in experiment $\mathrm{B}$, did not respond to $\mathrm{P}$ fertilization as far as the size of the yield was concerned.

The effects of $\mathrm{P}$ fertilization on the yields of single experimental years were also studied.

\section{Experiment $A$}

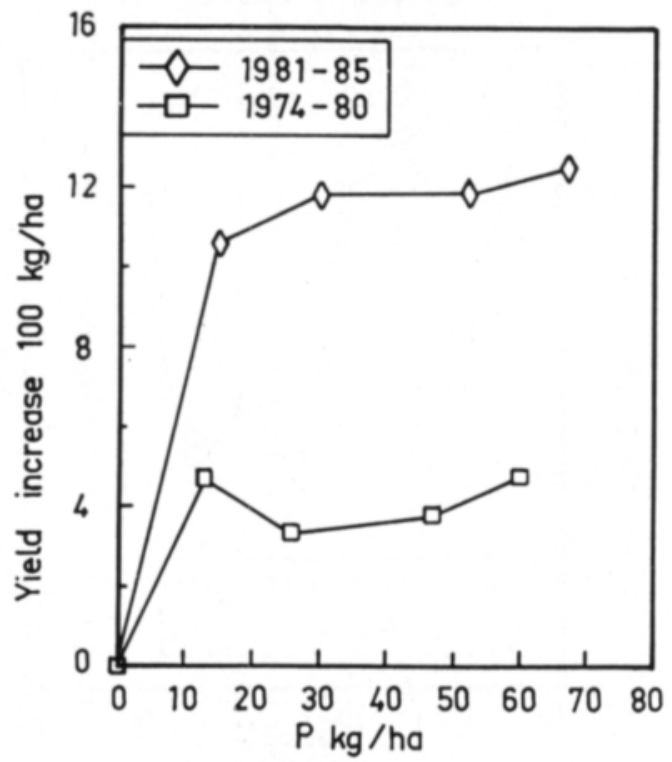

\section{Experiment $B$}

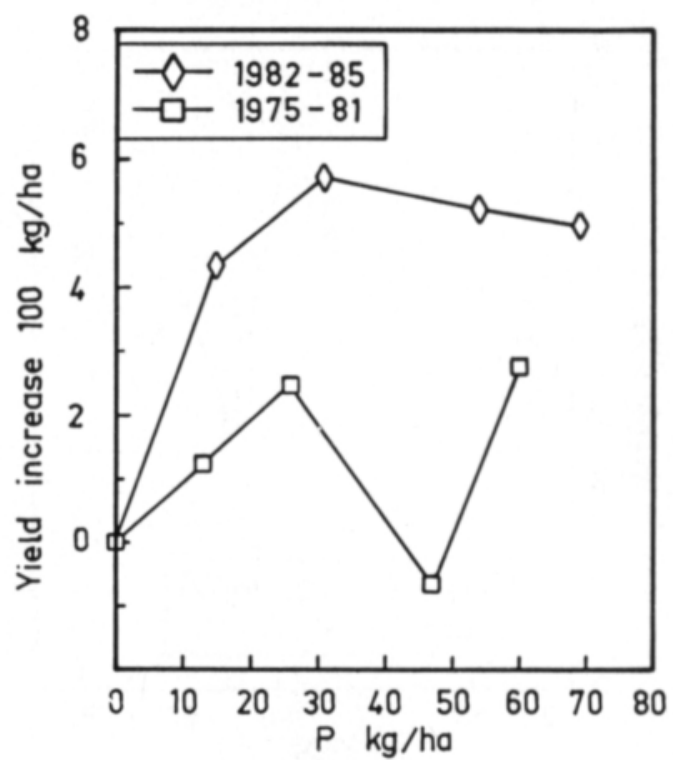

Fig. 2. Response of the yields of cereal crops to repeated applications of different rates of $\mathrm{P}$ fertilization. 
In experiment $\mathrm{A}, \mathrm{P}$ fertilization increased grain yields in 10 out of 12 , the nonexistent response occurring in the 2 nd and 3 rd experimental years. In experiment $\mathrm{B}$, the yields obtained from the plots fertilized with $\mathrm{P}$ were statistically significantly greater only in the 5 th, 9th, 10th and 11th experimental year. Based on the magnitude of the response to $\mathrm{P}$ fertilization by grain crops, the experiments were divided into two periods (Fig. 2). During the first part, consisting of seven years (1974-80) in experiment $\mathrm{A}$, the maximum yield was reached at the $\mathrm{P}$ rate of $13 \mathrm{~kg} / \mathrm{ha}$, at which $470 \mathrm{~kg} / \mathrm{ha}(12 \%)$ more grain was obtained, compared to the plots not fertilized with $\mathrm{P}$. In the latter period $(1981-85)$, the yield increase, attributable to $\mathrm{P}$ fertilization of $13 / 16 \mathrm{~kg} / \mathrm{ha}$, was as much as $1060 \mathrm{~kg} / \mathrm{ha}$ (33\%). Differing from the earlier years, the maximum yield during the last three seasons (1983-85) in experiment A was reached at the $\mathrm{P}$ rate of $32 \mathrm{~kg} / \mathrm{ha}$, at which the yields were $1360 \mathrm{~kg} / \mathrm{ha}(40 \%)$ greater than those obtained without $P$ fertilization. In experiment $\mathrm{B}$, the maximum yields were obtained at the $P$ rate of $26 / 32 \mathrm{~kg} /$ ha throughout the experimental period. During the earlier part (1975-81) of experiment B, the average yield increase of cereal grains, attributable to $\mathrm{P}$ fertilization, was $250 \mathrm{~kg} / \mathrm{ha}(6 \%)$, but during the latter part (1983-85), it was increased up to $570 \mathrm{~kg} / \mathrm{ha}(12 \%)$. According to the paired $\mathrm{t}$ test (Steel and Torrie 1980), the average increases in yields of cereal crops were also statistically significantly greater during the latter period of the trials, the test values being $\mathrm{t}=39.35^{* * *}$ and $4.56^{*}$ in experiment $\mathrm{A}$ and $B$, respectively.

When $\mathrm{P}$ fertilization was increased from 0 to $13 / 16 \mathrm{~kg} \mathrm{P} / \mathrm{ha}$, the moisture content of cereal grains at harvest decreased by 1.8 and 1.0 percentage points on average in experiment $\mathrm{A}$ and $\mathrm{B}$, respectively. In the six wet growing seasons, when the moisture content at harvest was more than $30 \%$, the corresponding difference was as much as 3.5 percentage points, which indicates that $\mathrm{P}$ fertilization had speeded up the development of the crop. The difference was smaller in dry years. Additional decrease in the moisture content of the grains did not occur as a result of $\mathrm{P}$ rates beyond the level at which the maximum yield was reached.

The phosphorus concentration in the cereal grains did not depend on the size of the yield or on the cereal grain species cultivated, and it was only slightly elevated by $\mathrm{P}$ fertilization (Table 5). The effect of $\mathrm{P}$ fertilization on the $P$ concentration was more prominent in the oil seed crops, which also had a considerably higher concentration of $\mathrm{P}$ than did the cereal grains. The differences in $\mathrm{P}$ concentration of the cereal grains were much greater between the yields obtained in different years than the ones attributable to $\mathrm{P}$ fertilization within a given year. The uptake of $\mathrm{P}$ by the crop was enhanced by $\mathrm{P}$ fertilization in both experiments, mainly owing to the increase in the size

Table 5. Phosphorus content of the grains or seeds receiced from plots fertilized with different quantities of $\mathrm{P}^{*}$.

\begin{tabular}{|c|c|c|c|c|c|c|}
\hline \multirow{2}{*}{$\begin{array}{l}\text { Fertilization } \\
\mathrm{kg} \mathrm{P} / \mathrm{ha}\end{array}$} & \multicolumn{3}{|c|}{$\mathrm{P}$ in dry matter } & \multicolumn{3}{|c|}{ Uptake of P } \\
\hline & $\begin{array}{c}\text { Exp A \# } \\
\mathrm{g} / \mathrm{kg}\end{array}$ & $\begin{array}{c}\text { Exp. B \# } \\
\mathrm{g} / \mathrm{kg}\end{array}$ & $\begin{array}{l}\text { Oil seeds } \\
\mathrm{g} / \mathrm{kg}\end{array}$ & $\begin{array}{c}\text { Exp. A \# } \\
\mathrm{kg} / \mathrm{ha}\end{array}$ & $\begin{array}{c}\text { Exp. B \# } \\
\mathrm{kg} / \mathrm{ha}\end{array}$ & $\begin{array}{c}\text { Oil seeds } \\
\mathrm{kg} / \mathrm{ha}\end{array}$ \\
\hline 0 & $3.6^{b}$ & $3.7^{\mathrm{b}}$ & $7.8^{d}$ & $11.7^{c}$ & $14.1^{\mathrm{e}}$ & $13.1^{\mathrm{b}}$ \\
\hline $13 / 16$ & $3.6^{b}$ & $3.8^{\mathrm{b}}$ & $8.6^{c}$ & $13.8^{\mathrm{b}}$ & $14.9^{b}$ & $14.1^{\mathrm{b}}$ \\
\hline $26 / 32$ & $3.6^{b}$ & $3.8^{b}$ & $8.9^{b}$ & $13.9^{\mathrm{b}}$ & $15.4^{\mathrm{ab}}$ & $16.7^{\mathrm{a}}$ \\
\hline $47 / 56$ & $3.7^{a}$ & $3.8^{b}$ & $9.2^{a}$ & $14.4^{\mathrm{ab}}$ & $14.6^{\mathrm{be}}$ & $15.5^{\mathrm{a}}$ \\
\hline $60 / 72$ & $3.7^{a}$ & $3.9^{\prime}$ & $9.3^{a}$ & $14.6^{\mathrm{a}}$ & $15.8^{\mathrm{a}}$ & $16.3^{\mathrm{a}}$ \\
\hline
\end{tabular}

- Each column has been tested separately. Means with a common letter are not different at the $95 \%$ level of statistical probability.

\# Cereal crops 
of the yields. Considerable quantities of $\mathrm{P}$ were mined from the soil by the crops grown without $\mathrm{P}$ fertilization. In the last experimental year, the crop in experiment A was still able to extract as much as $11.6 \mathrm{~kg} \mathrm{P} /$ ha from the plots not fertilized with $\mathrm{P}$ in 12 years although, at that point, the yield formation was already seriously limited by the poor supply of $\mathrm{P}$, as indicated by the yield increase of $32 \%$ in the plots receiving $32 \mathrm{~kg} \mathrm{P} / \mathrm{ha}$.

The $\mathrm{P}$ balances of the plots were calculated as differences between the quantities of $\mathrm{P}$ given in fertilizers and those removed via the crops (Table 6). The plots receiving no $\mathrm{P}$ fertilization were depleted by 141 and $153 \mathrm{~kg} / \mathrm{ha}$ in experiment $\mathrm{A}$ and $\mathrm{B}$, respectively. The plots receiving $13 / 16 \mathrm{~kg} \mathrm{P} /$ ha yearly did not gain or lose $\mathrm{P}$, and $\mathrm{P}$ was accumulating in the plots receiving higher rates of $\mathrm{P}$. Residual $\mathrm{P}$ had accumulated in forms extractable with $\mathrm{NH}_{4} \mathrm{~F}$ ("Al-P") and in experiment B also with $\mathrm{NaOH}$ ("Fe-P") (Table 7). The fraction extracted with $\mathrm{H}_{2} \mathrm{SO}_{4}$ ("Ca-P") had increased slightly in experiment $\mathrm{A}$. In absolute amounts, both "Al-P"' and "Fe-P'" were equally affected by the fertilization treatments, but due to the smaller quantity of "Al-P', the relative changes in this fraction were more pronounced. Assuming the depth of the plough layer to be $25 \mathrm{~cm}$, the recovery of residual $\mathrm{P}$

Table 6. Inputs and outputs of $\mathrm{P}$ during the experimental period of 12 years (experiment A) and 11 years (experiment B) as well as the P status of the plots at the end of the trials.

\begin{tabular}{|c|c|c|c|c|c|}
\hline $\begin{array}{l}\text { Fertilization } \\
\mathrm{kg} \mathrm{P} / \mathrm{ha}\end{array}$ & $\begin{array}{c}\text { Total input } \\
\mathrm{kg} \mathrm{P} / \mathrm{ha}\end{array}$ & $\begin{array}{c}\text { Carried away } \\
\text { in the yields } \\
\mathrm{kg} \mathrm{P} / \mathrm{ha}\end{array}$ & $\begin{array}{c}\text { Balance } \\
\text { in the soil } \\
\mathrm{kg} \mathrm{P} / \mathrm{ha}\end{array}$ & $\begin{array}{c}\mathrm{P}_{\mathrm{AMAc}}{ }^{*} \\
\mathrm{mg} / \mathrm{l}\end{array}$ & $\begin{array}{c}\mathrm{P}_{w^{*}} \\
\mathrm{mg} / \mathrm{kg}\end{array}$ \\
\hline & & & periment $\mathrm{A}$ & & \\
\hline 0 & - & 141 & -141 & $2.1^{\mathrm{b}}$ & $2.5^{c}$ \\
\hline $13 / 16$ & 166 & 165 & 1 & $3.8^{a}$ & $3.6^{c}$ \\
\hline $26 / 32$ & 333 & 166 & 167 & $4.3^{a}$ & $5.1^{\mathrm{b}}$ \\
\hline $47 / 56$ & 583 & 171 & 412 & $5.1^{\mathrm{a}}$ & $7.3^{\mathrm{a}}$ \\
\hline \multirow[t]{2}{*}{$60 / 72$} & 650 & 176 & 574 & $4.3^{a}$ & $5.5^{\mathrm{b}}$ \\
\hline & & & periment B & & \\
\hline 0 & - & 153 & -137 & 1.7 & $5.1^{\mathrm{c}}$ \\
\hline $13 / 16$ & 154 & 162 & -8 & $3.2^{\mathrm{bc}}$ & $6.7^{\mathrm{d}}$ \\
\hline $26 / 32$ & 309 & 171 & 138 & $5.2^{a b}$ & 9.4 \\
\hline $47 / 56$ & 541 & 162 & 379 & $5.1^{\mathrm{ab}}$ & $12.3^{\mathrm{b}}$ \\
\hline $60 / 72$ & 696 & 174 & 522 & 6.9 & $13.7^{\mathrm{a}}$ \\
\hline
\end{tabular}

* Each column and experiment has been tested separately. Means with a common letter are not different at the $95 \%$ level of statistical probability.

Table 7. Fractions of inorganic $\mathbf{P}$ at the end of the experiment.*

\begin{tabular}{|c|c|c|c|c|c|c|c|c|}
\hline \multirow{4}{*}{$\begin{array}{l}\text { Fertilization } \\
\mathrm{kg} \mathrm{P} / \mathrm{ha}\end{array}$} & \multicolumn{6}{|c|}{ P (mg/kg) extracted with } & \multirow{2}{*}{\multicolumn{2}{|c|}{$\begin{array}{l}\text { Sum of } \\
\text { fractions }\end{array}$}} \\
\hline & \multicolumn{2}{|c|}{$\mathrm{NH}_{4} \mathrm{~F}$} & \multicolumn{2}{|c|}{$\mathrm{NaOH}$} & \multicolumn{2}{|c|}{$\mathrm{H}_{2} \mathrm{SO}_{4}$} & & \\
\hline & \multicolumn{2}{|c|}{ Experiment } & \multicolumn{2}{|c|}{ Experiment } & \multicolumn{2}{|c|}{ Experiment } & \multicolumn{2}{|c|}{ Experiment } \\
\hline & A & B & A & B & A & B & A & B \\
\hline 0 & $69^{\circ}$ & $42^{c}$ & $151^{\mathrm{a}}$ & $150^{\circ}$ & $104^{b}$ & $230^{-2}$ & 324 & 422 \\
\hline $13 / 16$ & $91^{b}$ & 46 & $158^{a}$ & $158^{\mathrm{bc}}$ & $107^{b}$ & $236^{\prime \prime}$ & $356^{\mathrm{bc}}$ & $440^{b}$ \\
\hline $26 / 32$ & $109^{a b}$ & $77^{\mathrm{b}}$ & $165^{a}$ & $195^{b}$ & $112^{\mathrm{b}}$ & $216^{a}$ & $386^{\mathrm{ab}}$ & $494^{b}$ \\
\hline $47 / 56$ & $125^{a}$ & $95^{\text {ab }}$ & $173^{a}$ & $198^{b}$ & $121^{\mathrm{a}}$ & $236^{a}$ & 419 & $559^{a}$ \\
\hline $60 / 72$ & $108^{\text {ab }}$ & $120^{\mathrm{a}}$ & $162^{a}$ & $241^{\text {a }}$ & $121^{\mathrm{a}}$ & $242^{a}$ & $391^{\text {ab }}$ & 605 \\
\hline
\end{tabular}

* Each column and experiment has been tested separately. Means with a common letter are not different at the $95 \%$ level of statistical probability. 
Table 8. Apparent recovery of residual $\mathrm{P}$ in the plough layer.

\begin{tabular}{lccccc}
\hline \multirow{2}{*}{$\begin{array}{l}\text { Fertilization } \\
\mathrm{kg} \mathrm{P} / \text { ha }\end{array}$} & \multicolumn{3}{c}{ Recovery of residual P } \\
\cline { 2 - 3 } & \multicolumn{3}{c}{ Experiment $\mathrm{A}$} & & \multicolumn{2}{c}{ Experiment B } \\
\cline { 2 - 3 } \cline { 5 - 6 } & $\mathrm{kg} / \mathrm{ha}$ & $\%$ & & $\mathrm{~kg} / \mathrm{ha}$ & $\%$ \\
\hline $13 / 16$ & 155 & 56 & & 45 & 35 \\
$25 / 32$ & 238 & 43 & & 165 & 60 \\
$47 / 56$ & 168 & 24 & & 468 & 52 \\
$60 / 72$ & & & & &
\end{tabular}

in each plot was calculated as the quantity of total fractionated $\mathrm{P}$ from which the quantity of $\mathrm{P}$ in the plots not receiving $\mathrm{P}$ during the experiment was subtracted (Table 8). These quantities were compared to the theoretical differences created by fertilization and $\mathrm{P}$ uptake of the crop and calculated from the data in Table). In terms of inorganic P, the plots fertilized and not fertilized with $\mathrm{P}$ differed from each other less than expected, and the recovery of residual $\mathrm{P}$ was no more than 24$71 \%$ of the theoretical quantities.

The soil analyses performed during the ex- periments (Fig. 3) showed that in experiment $\mathrm{B}$, the quantities of $\mathrm{P}_{\mathrm{AAAc}}$ were continuously decreasing in the plots receiving no $\mathrm{P}$ or $13 / 16$ $\mathrm{kg} \mathrm{P} /$ ha yearly. The ones fertilized with $26 / 32$ $\mathrm{kg} \mathrm{P} / \mathrm{ha}$ or $49 / 56 \mathrm{~kg} \mathrm{P} / \mathrm{ha}$ (not shown in Fig. 3) somewhat maintained the original level of $\mathrm{P}_{\mathrm{AAAc}}$. Even in the plots receiving $60 / 72 \mathrm{~kg}$ $\mathrm{P} /$ ha yearly, no marked increase of $\mathrm{P}_{\mathrm{AAAC}}$ was measured. In experiment $\mathrm{A}$ the soil analyses did not show equally clear trends in any of the various $\mathrm{P}$ treatments. Nevertheless, at the end of the experimental period the level of $\mathrm{P}_{\mathrm{AAAc}}$ was the higher the more $\mathrm{P}$ had been applied to the plot, with the exception of plots receiving $60 / 72 \mathrm{~kg} \mathrm{P} /$ ha (Table 6). According to the paired $t$ test, the differences in $\mathrm{P}_{\mathrm{AAAc}}$ extracted from the plots receiving the same fertilization in the two experiments were practically nonexistent at the end of the experiments $\left(t=0.86^{\text {n.s. }}\right)$. However, extraction of $\mathrm{P}$ with water $\left(\mathrm{P}_{\mathrm{w}}\right)$ revealed considerable differences between the two experiments. The quantities of $\mathrm{P}_{\mathrm{w}}$ were higher in experiment $\mathrm{A}$ when the corresponding plots of the two experiments were compared $\left(t=4.71^{* *}\right)$.

\section{Experiment $A$}

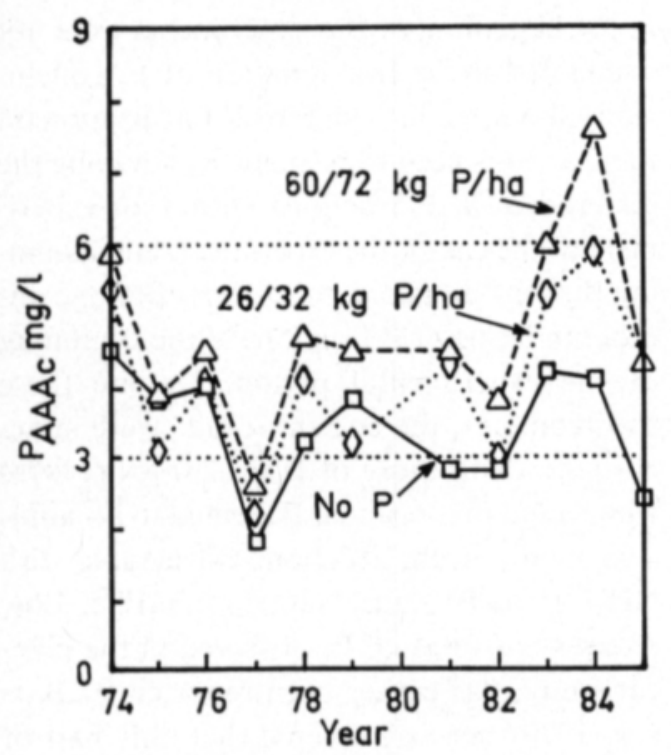

\section{Experiment $B$}

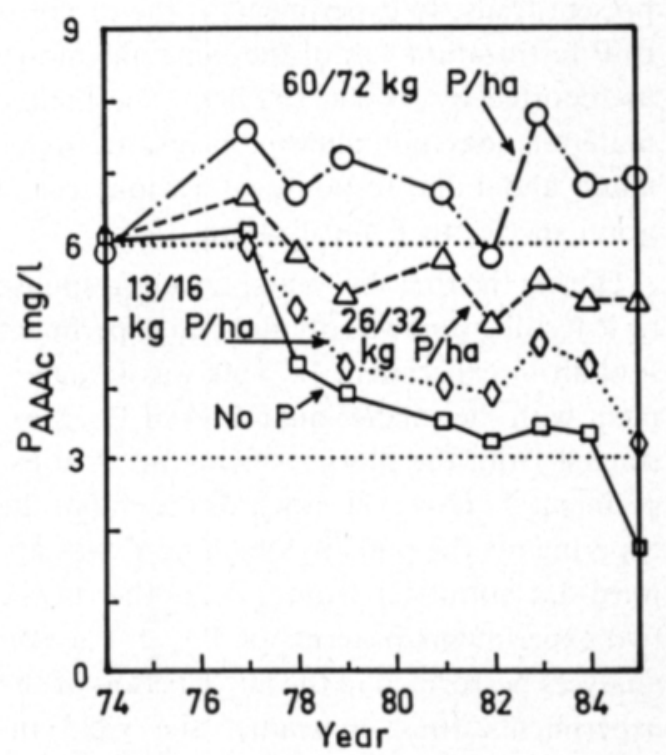

Fig. 3. Development of the quantities of $\mathrm{P}$ extracted with $0.5 \mathrm{M} \mathrm{NH}_{4}$-acetate- $0.5 \mathrm{M}$ acetic acid at $\mathrm{pH} 4.65$ $\left(\mathrm{P}_{\mathrm{AMA}}\right)$ in the plots fertilized with different rates of $\mathrm{P}$. 


\section{Discussion}

In a long-term experiment on $\mathrm{P}$ fertilization, residual $\mathrm{P}$ accumulates in the plots fertilized with $\mathrm{P}$; in plots not receiving this nutrient, $\mathrm{P}$ is continuously depleted. Repeated $P$ treatments thus lead to a continuous differentiation of the plots in terms of the $\mathrm{P}$ status of the soil, a phenomenon disclosed in both of the present experiments. Therefore, the response to $\mathrm{P}$ fertilization in such experiments must be considered a function of current $\mathrm{P}$ fertilization as well as of residual $\mathrm{P}$ accumulated in the soil since the beginning of the trial. The most important outcome of the present experiments may indeed be the documentation of the phenomenon that the apparent response to $\mathrm{P}$ fertilization was increasing over time, as was also reported by $\mathrm{LI}$ and Barber (1988). However, it must be pointed out that the phenomenon was due to the depletion of the plots receiving no $\mathrm{P}$ fertilization, which was used as the reference level. The overall response to $\mathrm{P}$ fertilization in experiment $\mathbf{A}$ was as much as double the response obtained by SAARELA (1989) in a series of field experiments in which cereal grains were cultivated for 10 years in soils which in terms of $\mathrm{P}_{\mathrm{AANC}}$ were in the same range as the present trials. In experiment $\mathbf{A}$, the response to $\mathrm{P}$ fertilization was of the same magnitude as reported by SaArela (1989). The limited material does not allow conclusions to be made about the response of various cereal grain species to $\mathrm{P}$ fertilization.

During the first few years, greater response to $\mathrm{P}$ fertilization was obtained in experiment A than in experiment B. This was in agreement with the smaller quantities of $\mathrm{P}_{\mathrm{AMA}}$ extracted from the plots receiving no $\mathrm{P}$ in experiment A. However, towards the end of the experiments the plots to which no $\mathrm{P}$ was applied did not differ from one another in the two experiments in terms of $\mathrm{P}_{\text {AAAc }}$. The soil analyses performed in the latter period of the experiments thus contradict the yield increases, which were much greater in experiment $\mathrm{A}$. This result suggests that despite the equal $\mathrm{P}_{\mathrm{AAAC}}$, the soil of experiment $\mathrm{A}$ had $\mathrm{a}$ poorer $\mathrm{P}$ status than that of experiment $\mathrm{B}$. The difference between the experimental soils was, however, disclosed by the water extraction, performed at the end of the trials. This observation is in line with other studies in which water extraction has been superior to the AAAc method in predicting yield increases obtained by $\mathrm{P}$ fertilization in field experiments (Sippola and SaArela 1986) or P uptake by plants in pot experiments (AurA 1978, SiPPOLA and JAAKKOLA 1980). It may be suggested that an AAAc extraction in which the soil: solution ratio is only 1:10 gives an estimate for $\mathrm{P}$ intensity. In turn, it was shown by Schachtschabel and Beyme (1980) that $\mathrm{P}_{\mathrm{w}}$, obtained at the wide soil:solution ratio of $1: 60$, also reflects the capacity of the soil to supply the plants with P. Further, an important observation was that even excessive $\mathrm{P}$ fertilization could not elevate the level of $\mathrm{P}_{\text {AAAc }}$ in either of the experiments. It remained an open question whether the residual $\mathrm{P}$ was really converted in the soil into forms unavailable to plants or whether the current result was an indication of the extensive $\mathrm{P}$ buffer capacity of the two soils rich in poorly crystalline $\mathrm{Al}$ and $\mathrm{Fe}$.

Due to the fact that the soil samples taken at the beginning of the experiments were not available for the fractionation of $\mathrm{P}$, conclusions about the influence of $\mathrm{P}$ fertilization on the fractions need to be made by studying the differences in $\mathrm{P}$ fractions within an experiment at the end of the experiment, and assuming that the plots did not differ from one another in terms of $\mathrm{P}$ fractions at the beginning of the experimental period. Despite these shortcomings, the current results were in accordance with those of HARTIKAINEN (1989a) who found that residual $P$ seemed to accumulate mainly in the fractions extractable with $\mathrm{NH}_{4} \mathrm{~F}$ ("'Al-P') and $\mathrm{NaOH}$ ('Fe-P'). Low recovery of residual $\mathrm{P}$, observed in the present study, has earlier been reported by BARBER (1979), who discovered that only half of the calculated quantity of residual $\mathrm{P}$ was recovered when total $\mathrm{P}$ was determined at the end 
of a 25-year field experiment. Among the several processes which contribute to the low recovery of fertilizer $\mathrm{P}$, major effects by erosion can be excluded in the present experiments due to the flatness of the area, and leaching of $\mathrm{P}$ seems unprobable in soils rich in poorly crystalline $\mathrm{Al}$ and $\mathrm{Fe}$. Net transformation of $\mathrm{P}$ into organic phosphates, suggested to be important by WAGAR et al. (1986), or occlusion of P into inorganic forms not extracted in the fractionation procedure, may explain part of the low recovery. An additional explanation may be exchange of soil between the plots. In a Danish study by SıвBESEN (1986) it turned out that the net import of soil richer in $\mathrm{P}$ from the adjacent plots had more than compensated the export of $\mathrm{P}$ in the harvested crop in the plots not receiving $\mathrm{P}$ fertilization in two 90 -year field experiments. The plots which according to the experimental design got no $\mathrm{P}$ fertilization, have probably gained soil from other plots richer in $\mathrm{P}$ also in the present trials. Supplement $\mathrm{P}$ entering these plots along with the imported soil material evidently increased the quantities of inorganic P measured upon fractionation. Since the recovery of residual $P$ was calculated as the difference in the quantities of inorganic $\mathrm{P}$ measured in the plots fertilized and not fertilized with $\mathrm{P}$, import of soil inevitably results in low apparent recovery of residual $\mathrm{P}$.

In experiment $\mathrm{B}$, the difference in yields obtained from the plots fertilized and not ferti- lized with $\mathrm{P}$ exceeded $10 \%$ only in the last few years. This indicates that major accumulation of plant-available residual $\mathrm{P}$ had occurred in the soil prior to the experiment. In experiment $\mathrm{A}$, the pool of labile $\mathrm{P}$ was less extensive, since a response to $\mathrm{P}$ fertilization was obtained from the very first experimental year. Even though the fertilization with $13 \mathrm{~kg}$ $\mathrm{P} /$ ha was sufficient for most of the experimental period, the yields at that $\mathrm{P}$ rate were obviously produced at the expense of the labile $\mathrm{P}$ reserves of the soil. Fertilization with $13 / 16 \mathrm{~kg} \mathrm{P} /$ ha was not able to prevent those reserves from decreasing below the critical level. This was indicated by the fact that during the last few years in experiment $A$, the maximum yields were obtained at a higher $\mathrm{P}$ level, $32 \mathrm{~kg} / \mathrm{ha}$. The present experiments demonstrate that if the soil contains considerable reserves of plant-available $\mathrm{P}$ at the beginning of the experiment, the results of the first few years prompt recommendations for $\mathrm{P}$ fertilization that are too low in the long run. The long-term requirement of $\mathrm{P}$ fertilization in the cultivation of cereal crops in the current experiments was approximately double the export of $\mathrm{P}$ in the grain yields. At that $\mathrm{P}$ rate, it was possible to maintain both the maximum yields and the intensity of $\mathrm{P}$ in the soil.

Acknowledgment. The author wishes to thank Mr. Auvo Leskelä, former head of Kotkaniemi experimental farm, for the design and management of the field experiments.

\section{References}

ANON. 1987. Viljavuustutkimuksen tulkinta peltoviljelyssă. Viljavuuspalvelu Oy. 70 p.

AurA, E. 1978. Determination of available soil phosphorus by chemical methods. J. Scient. Agric. Soc. Finl. 50: 305-316.

Barber, S.A. 1979. Soil phosphorus after 25 years of cropping with five rates of phosphorus application. Commun. Soil. Sci. Pl. Anal. 10: 1459-1468.

Hartikainen, H. 1979. Phosphorus and its reactions in terrestrial soils and lake sediments. J. Scient. Agric. Soc. Finl. 51: 537-624.

- 1982. Water soluble phosphorus in Finnish mineral

soils and its dependence on soil properties. J. Scient. Agric. Soc. Finl. 54: 89-98.

- 1989a. Effect of cumulative fertilizer dressings on the phosphorus status of mineral soils. I Changes in inorganic phosphorus fractions. J. Agric Sci. Finl. 61: 55-59.

- 1989b. II Comparison of two phosphorus testing methods. J. Agric. Sci. Finl. 61: 61-66.

Jankovic, M. \& Nemeth, K. 1979. Einfluss langjährig gesteigerter K- und P-Düngung auf die K- und PDynamik im Boden sowie auf den Ertrag. Landw. Forsch. 32: 283-291. 
LI, R.-G. \& Barber, S.A. 1988. Effect of phosphorus and potassium fertilizer on crop response and soil fertility in a long-term experiment. Fertilizer Res. 15: 123-136.

Mclaughlin, M.J., Atston, A.M. \& Martin, J.K. 1988. Phosphorus cycling in wheat-pasture rotations. I. The source of phosphorus taken up by wheat. Austr. J. Soil. Res. 26: 323-331.

SAAREla, I. 1989. Fosforilannoitus taloudelliseksi ja ympäristöystävälliseksi. Käytănnön Maamies 38: 3: 36-39.

SAARI, E. \& PAASO, A. 1980. Mineral element composition of Finnish foods. II Analytical methods. Acta Agric. Scand. Suppl. 22: 15-25.

Schachtschabel, P. \& Beyme, B. 1980. Löslichkeit des anorganischen Bodenphosphors und Phosphatdüngung. Z. Pflanzenernähr. Düng. Bodenkd. 143: 306-316.

Sharpley, A.N. 1986. Disposition of fertilizer phosphorus applied to winter wheat. Soil. Sci. Soc. Amer. J. 50: $953-958$.

\section{SELOSTUS}

\section{Fosforilannoituksen vaikutus satoon ja maan fosforitilaan kahdessa pitkäaikaisessa kenttäkokeessa}

\author{
Markku Yli-Halla \\ Kemira $O y$ \\ 02271 Espoo
}

Kemira Oy:n Kotkanicmen Koetilalla tehtiin v. 1974-85 hiesusavimaalla kaksi kenttäkoetta (Koe A ja B), joissa tutkittiin erisuuruisten P-lannoitusmäărien vaikutusta paaasasiassa viljakasvien satoon ja maan P-tilaan. Koejakson alussa oli maassa ammoniumasetaattiliuokseen (pH 4.65) uuttuvaa fosforia $5.5 \mathrm{mg} / \mathrm{l}$ (Koe A) ja $6.2 \mathrm{mg} / \mathrm{l}$ (Koe B). Viljavuusanalyysin tulkintaohjeen (ANON 1987) mukaan kokeen A P-tila oli "vălttävă" ja kokeen B P-tila "'tyydyttăvă'. Fosforilannoitusmäärăt olivat v. $1974-820,13,26,47$ ja $60 \mathrm{~kg} / \mathrm{ha}$ ja $1983-850,16,32$ 56 ja $72 \mathrm{~kg} /$ ha. Fosforilannoitus annettiin sijoituslannoituksena koetta varten valmistettuja NPK-lannoitteita käyttäen. Kokeessa $\mathrm{A}$ saatiin maksimisato aina yhdeksänteen koevuoteen asti P-tasolla $13 \mathrm{~kg} / \mathrm{ha}$ ja viimeisină koevuosina P-tasolla $32 \mathrm{~kg} / \mathrm{ha}$. Kokeen alkupuolella (1974-80) oli maksimisato keskimäärin $470 \mathrm{~kg} / \mathrm{ha} \mathrm{(12 \% )}$ suurempi kuin ilman P-lannoitusta viljellyiltä ruuduilta saatu jyväsato. Kokeen loppupuolella (1981-85) ilman
Sibresen, E. 1986. Soil movement in long-term field experiments. Plant and Soil 91: 73-85.

Sippola, J. \& JaAKKol.A, A. 1980. Maasta eri menetelmillä määritetyt typpi, fosfori ja kalium lannoitustarpeen osoittajina astia- ja kenttäkokeissa. Maatalouden tutkimuskeskus. Maanviljelyskemian ja -fysiikan laitos. Tiedote 13: 24-41.

- \& Sanrel.A, I. 1986. Some extraction methods as indicators of need for phosphorus fertilization. Ann. Agric. Fenn. 25: 265-271.

Steel, R.G.D. \& Torrie, H.J. 1980. Principles and procedures of statistics. A biometrical approach. 633 p. 2 nd Ed. Singapore.

Vuorinen, J. \& MAкitie, O. 1955. The method of soil testing in use in Finland. Agrogeol. Publ. 63, 44 p. Helsinki,

Wagar, B.I., Stewart, J.W.B. \& Molr, J.O. 1986. Changes with time in the form and availability of residual fertilizer phosphorus on chernozemic soils. Can. J. Soil Sci. 66: 105-119.

Ms received August 31,89

P-lannoitusta viljeltyjen ruutujen P-varat ehtyivăt siinä määrin, ettă P-lannoitus tuotti sadonlisãystả keskimaaărin $1360 \mathrm{~kg} / \mathrm{ha}(40 \%)$. Kokeessa B P-lannoituksella saatiin pienempiä sadonlisảyksiä, jotka kuitenkin kasvoivat kokeen loppua kohti ollen enimmillaaăn (1983-85) 570 $\mathrm{kg} /$ ha $(12 \%)$. P-lannoitus alensi puintikosteutta erityisesti märkină vuosina. Ilman P-lannoitusta viljellyillă ruuduilla asetaattiliuokseen uuttuneet $\mathrm{P}$-mäărăt alenivat jyrkästi ollen kokeiden lopussa $1.8 \mathrm{mg} / \mathrm{l}$ (Koe A) ja $2.2 \mathrm{mg} / \mathrm{l}$ (Koe B). Asetaattiuuttoisen P:n mäără maassa ei kohonnut edes runsaimman P-lannoituksen saaneilla ruuduilla. Maahan jäänyt $P$ oli kertynyt paaaasiassa raudan ja alumiinin sitomiin fraktioihin. Optimaalisen P-lannoitustason mảảrittảmiseksi on tehtảvă riittävăn pitkảaikaisia kenttäkokeita. Vain muutamia vuosia kestävien kokeiden perusteella saadaan lannoitussuosituksia, jotka ovat pitkän päälle liian alhaisia. 